\title{
Studies of Decomposition rate and release of nutrients Ammonium, Nitrates, Nitrites, and Phosphates ions during the decomposition of Oryza coarctata in the laboratory experiment.
}

\author{
Zafar Farooqui $^{1}$, P.J.A. Siddiqui ${ }^{*}$, Seema Shafique ${ }^{1}$, Munawwer Rasheed ${ }^{2}$ \\ ${ }^{1}$ Center of Excellence in Marine Biology, University of Karachi, Karachi \\ ${ }^{2}$ Department of Chemistry, University of Karachi, Karachi
}

\section{ABSTRACT}

The vegetation, other than the mangroves in Indus delta, for example Oryza coarctata is also the source of nutrients for the adjacent coastal environment. The O. coarctata is the major vegetation on the tidal mudflatds of Keti-Bunder (Hajambro creek), Indus delta, other than the Avicennia marina and Rhizophora mucronata planted mangrove forest. This is the first report of decomposition rates of $O$. coarctata in the laboratory. The decomposition of $O$. coarctata. was conducted to evaluate the nutrients (ammonium, nitrate, nitrites, phosphates) during the decomposition. The decomposition rate was more rapid during this early phase and $O$. coarctata. decomposed up to $40 \%$ during the first 7 days. Afterwards, the Oryza sp. decomposed slowly and gradually and remained up to $40 \%$ of the dry mass. Therefore, about $60 \%$ of the organic matter present in the O. coarctata can decompose completely in the aerobic conditions of the aquatic environment. The ammonium ions concentration was found 2.75 $\mu \mathrm{M} / \mathrm{L}$ at 7 th day and highest value was $6.38 \mu \mathrm{M} / \mathrm{L}$ at 124 th day of experiment. So the amount of ammonium ions increased during the phase of decomposition. The nitrate ions concentration was 1.95 $\mu \mathrm{M} / \mathrm{L}$ at 7 th day and increased to $2.71 \mu \mathrm{M} / \mathrm{L}$ at 15 th day of decomposition, and afterwards the concentration of nitrate decreased gradually and lowest value $0.129 \mu \mathrm{M} / \mathrm{L}$ was recorded in the last day of the experiment. The nitrite ions concentration was found $1.80 \mu \mathrm{M} / \mathrm{L}$ and gradually increased to $3.33 \mu \mathrm{M} / \mathrm{L}$ at 60 th day and the lowest value was $3.05 \mu \mathrm{M} / \mathrm{L}$. The initial concentration of the phosphate ions was 0.84 and decresed gradually during the phase of decomposition to its lowest value at 0.7 $\mu \mathrm{M} / \mathrm{L}$. The concentration of the nitrogen in the O. coarctata was initially between 1-1.5 mg DW, which increased to about $2 \mathrm{mg} \mathrm{DW}$ at the 7 th day of the decomposition. The \% DW nitrogen contents than decreased suddenly at 15 th day reaching up to about $1 \mathrm{mg}$ DW of the decomposed material. This decrease of the total DW Nitrogen is very important, as it is the source of the nutrients to the adjacent ecosystem. The results are also strongly correlated with the nutrients values.
\end{abstract}

Keywords: Hajamrbro Creek, Indus Delta, Oryza coarctata, decomposition, Nutrients.

\section{INTRODUCTION}

The vegetation, other than the mangrove plant's leaves in Indus delta (eg Oryza coarctata in Hajambro creek) is the important source of nu trients flow in the estuarine ecosystem $[1,2]$.

\footnotetext{
* Corresponding author:

Pirzada Jamal Siddiqui

Government Degree Boys Colege, KMC-Store, Nishtar Road, Karachi-75270

Email: zafar_researchfellow@yahoo.com
}

Because the leaves production of $O$. coarctata release is very high and sustained throughout the year (personnel observation). Once the leaves are detached from the plant, they float, and are transported away with the water flow [2, 3, 4]. A significant portion of the leaf wrack and than decomposed in the creek waters.

It is therefore essential to determine the role of the vegetation in the nutrients flow dynamic and to analyze the litter component in more 
detail, studying production, decay, export and burial of litter [1, 2, 3, 4, 5].

Because the importance of vegetation other than mangrove has become increasingly recognized over the last decades for their contribution to the productivity of the world's oceans. These marine vegetations are the physical and biological foundation for many coastal marine systems $[1,2$, 5]. Despite the difficulty of discerning their roles as food source, determining the fate of the carbon they fix and examining the trophic routes through which vegetation production is transferred to higher trophic levels is crucial to un derstand the food web of coastal ecosystems [6].

Therefore the study of litter dynamics is now adays seen as a prerequisite for understanding the high productivity of these systems $[5,7,8]$. The detrital food web has long been inferred to be the major trophic path of energy flow in coastal systems [6].

The decay of vascular plants occurs in three phases: (1) an early phase lasting less than one month, with fast rates of weight loss due to the leaching of soluble compounds, (2) a slower phase lasting up to one year, including microbial degradation of organic matter and subsequent leaching of hydrolyzed substances, and (3) a very slow decay phase of remaining refractory ma terials, which may last an additional year, as describe by Valiela [9].

There are several factors affecting the of the plant fragments, including the microorganisms, elemental content of plant $[6,10]$. Environ mental factors like temperature, availability of both water and nutrients and on the fragmentation by detritivores etc $[6,11,12,13]$. The bacterial assimilation of nutrients from the environment is thought to be necessary for the decomposition of plant material of low initial nutrient content, particularly nitrogen [11, 12].

In the present study, we investigated the nitrogen contents during decomposition and nutrients released during the early phase of de composition in the $O$. coarctata, which determines that the decomposition is the source of nutrients ions (ammonium, nitrates, nitrites and phos phates).

The aim of this study was to assess the changes in the concentration of total nitrogen during the decomposition rate of Oryza coarctata, and changes in the concentartion of nutrients (ammonium, nitrate, nitrite and phosphate) released during decomposition.

\section{MATERIALS AND METHODS}

\section{Study Area}

The Indus delta is situated at $24^{\circ} 08^{\prime} 789^{\prime \prime}$ and $067^{\circ} 27^{\prime}$ 187" $^{\prime \prime}$ E (Hjamro Channel) approxi mately at the distance of about $170 \mathrm{Km}$ from Karachi (Figure 1). The Indus River in Pakistan has the seventh largest delta supplied by eighth largest drainage area in the world [14]. During the summer monsoon seawater inundated both the active and inactive parts of the delta, leaving behind evaporated salt deposition during its retreat.

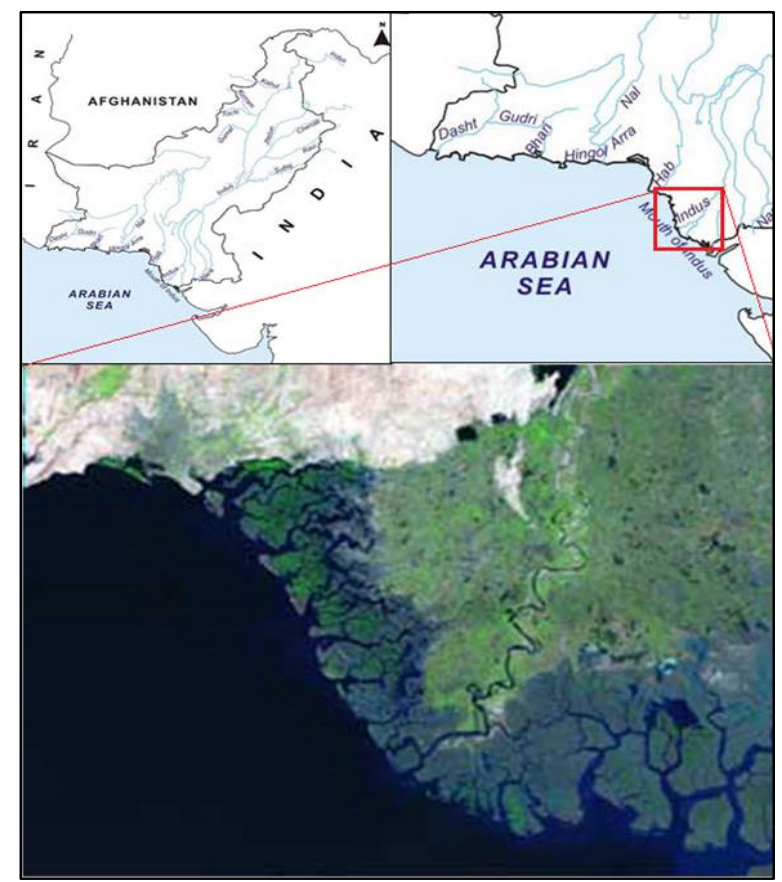

Figure 1 Map showing location of Indus delta mangroves where the Oryza coarctata were collected for the decomposition rate studies in the laboratory of Centre of Excellence in Marine Biology, University of Karachi.

The most significant feature about the Indus river is the greater variation in flow levels with peak annual flood water in summer, from melting of Himalayan snows and glaciers, coupled with the annual monsoon rains, followed by great shrinkage in water flow during the almost rainless winter months [15], though the monsoon which reaches Pakistan is relatively weak and of short 
duration, falling largely in July-August, the river flow can increase by fifty times from its midwinter lowest levels. The Indus River annual river flow is 275 million cubic yards of water, twice that of Nile [15].

Therefore, it can be said that the freshwater input into the delta has become very low, which has resulted into very stunted growth of the Avicennia marina. Because high salinity in most of the months of the year has effect on the growth of the mangroves. Avicennia marina is the high salt tolerant species of the mangroves. The high salinity conditions in the delta have resulted in very little luxuriant vegetation. Mangroves have been the dominant vegetation over much of the delta, which are now becoming severely restricted due to anthropogenic activities, mostly deforest ation and camel grazing (personal observations).

\section{Climate}

The hottest months in the area is May and June with temperature reaching $40^{\circ} \mathrm{C}$, while December and January are the coldest months with temperature $9^{\circ} \mathrm{C}$. Maximum precipitations occurs in the months of August, having 34.5 $\mathrm{mm}$ rainfall, which is the monsoon rainfall. Humidity reaches its maximum 60\% in August, mostly due to the rainy season, while the mini mum humidity (24\%) occurred in April and March. The wind speed is maximum in the month of July having 11.2258 Knots and min imum in August (10 Knots). Thus Pakistan faces relatively weak and of short monsoon duration. Water and sediment discharge is very low between October and April, and then increase to a maximum during August-September for water, and September for sediment, $80 \%$ of the water discharge occurs between May and October. The increase coincides with the peak of the monsoon rainy season, which can vary from year to year, but the annual cycle is predictable, with high discharge during the summer monsoon and low ones during the winter monsoon.

\section{Field Method}

The known weights of the aboveground material of the Oryza coarctata. was taken in the month of May 2005. The fresh O. coarctata. was collected from the field. The $O$. coarctata was washed with distilled water and the roots material were cut. Only the aboveground material was taken for the decomposition rate study.

\section{Laboratory Methods}

The known weight of the $O$. coarctata. was taken in 14 different jars. The jars were filled with the seawater of normal salinity. All the jars were fully aerated.

Replicate jars were atken at 7 th, 15th, 30th, 60 th and finally at 124 th day of experiment. The $O$. coarctata was sieved though $0.05 \mathrm{~mm}$ sieve and washed with distilled water. The washed material of $O$. coarctata was placed on blotting sheet in the Laboratory for twenty-four hours. The air-dried weight was taken. Then the $O$. coarctata was placed in the oven at $70^{\circ} \mathrm{C}$ for $24 \mathrm{~h}$ for the ovendried weight.

Nutrients (Ammonium, Nitrates, Nitrites and Phosphates) analysis The water collected from the sieves was stored frozen after adding few drops of Chloroform until analyzed with Hanna's Multiparameter Ion Specific photometer (Italy) for Nutrient (ammonium, nitrates, nitrites and phosphates) according to the prescribed methods. Another 3 sets of bottles were sieved for the decomposed O. coarctata after two weeks, one month, and two month respectively.

\section{Total Nitrogen analysis}

The total nitrogen in the decomposed fragments of $O$. coarctata was estimated by the Kjeldhal method.

\section{Statistical Analysis}

The relation ship between percent AFDW remaining (y) and sampling time (x) was deter mined by simple linear $(\mathrm{y}=\mathrm{a}+\mathrm{bx})$ as well as simple negative exponential $(\mathrm{y}=\mathrm{aekt})$ models.

\section{The Decomposition rate Constant:}

The decomposition rate constant (k) was obtained from the regression models and the half-life times $(\mathrm{t} 1 / 2)$ were then calculated according to the equation $\mathrm{t} 1 / 2=(\operatorname{In} 2) / \mathrm{k}$.

\section{RESULTS AND DISCUSSION}

\section{Decomposition rate}

The O. coarctata decomposes faster and the 
original weight (about $15 \mathrm{gm}$ ) was decreased to $5.01 \mathrm{gm}$ at 124th day of decomposition, which is about $66 \%$ of the dry mass remaining (Figure 2). The $O$. coarctata decomposed up to $40 \%$ during the first 7 days (Figure 3). The decomposition rate was more rapid during the early phase. Afterwards, the $O$. coarctata decomposed slowly and gradually and remained up to $40 \%$ of the dry mass. Therefore, about $60 \%$ of the organic matter present in the $O$. coartata decomposed completely in the aerobic conditions of the aquatic environment.

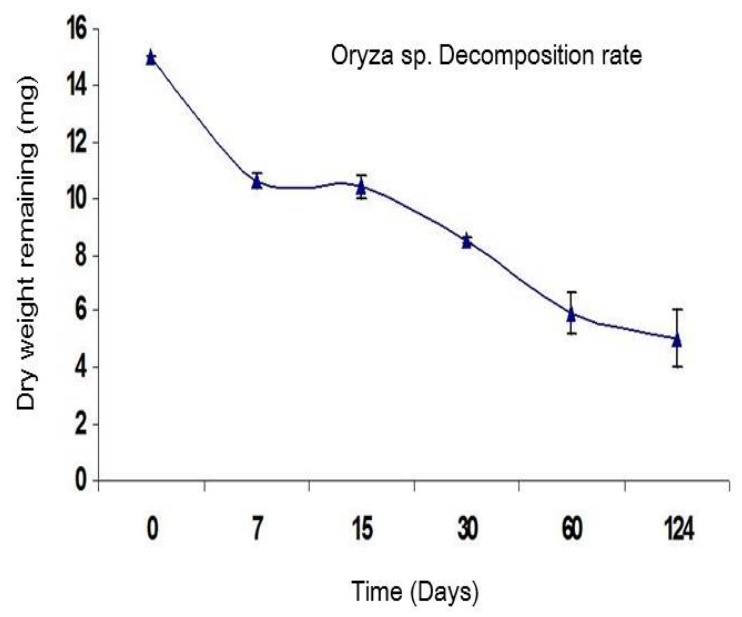

Figure 2 Mean dry weight from the original weight (15 gm) remaining during the decomposition of Oryza coarctata in the laboratory.

\section{Nitrogen concentrations}

The concentration of the nitrogen in the $\mathrm{O}$. coaractata was initially between 1-1.5 mg (dry weight) which increased to about $2 \mathrm{mg}$ at the 7 th day of the decomposition [Figure 4]. The initial increase in the Nitrogen contents was due to the deposition and growth of the microorganism on the O. coarctata. The micro-organism plays an important role in the decomposition of the plant material in the marine environment. The initial deposition and accumulation of the microorganism and bacteria, starts the process of the decomposition.

During this phase, the bacterial biomass increases, which was clearly evident the increase of $\% \mathrm{DW}$ nitrogen contents in the early phase of the decomposition [the 7 th day]. The $\%$ DW nitrogen contents than decreased suddenly at 15 th day reaching up to about $1 \mathrm{mg} \mathrm{DW}$ of the decomposed material (Figure 4). This decrease of the total DW nitrogen is very im-portant, as it is the source of the nutrients to the adjacent ecosystem decomposition. During this phase of the decomposition, the bacterial biomass increases, which was clearly evident in the increase of $\%$ DW Nitrogen contents at the early phase of the decomposition (the 7th day). The \% DW Nitrogen contents than decreased suddenly at 15 th day reaching up to about $1 \mathrm{mg}$ DW of the decomposed material (Figure 4). This decrease of the total DW Nitrogen is very important, as it is the source of the Nutrients to the adjacent ecosystem.

\section{Nutrients released during decomposition of Oryza coaractata}

\section{The Ammonium ion concentration}

The ammonium ions concentration was found $2.75 \mu \mathrm{M} / \mathrm{L}$ at 7 th day and highest value was 6.38 $\mu \mathrm{M} / \mathrm{L}$ at 124th day of experiment. So the amount of ammonium increases during the phase of decomposition (Figure 5).

Table 1 Simple Negative exponential regression equations ( $\mathrm{Y}=$ aekx or $\mathrm{Y}=\ln +\mathrm{Kx}$ ) on $\%$ of the decomposed Oryza coaractata material remaining in the glass Bottles, during the process of the decomposition in the laboratory, and its major nutrients (Total $\mathrm{N}$ ) remaining e $(\mathrm{Y})$ against time $(\mathrm{X})$ during decomposition.

\begin{tabular}{|llcccc|}
\hline $\begin{array}{c}\text { Litter Biomass } \\
\text { DW Remaining }\end{array}$ & Regression Equation & K (per wk) & K (perday) & $\begin{array}{c}\mathbf{T}_{1 / 2} \\
\text { (d) }\end{array}$ & $\begin{array}{c}\text { T 1/2 (per } \\
\text { week) }\end{array}$ \\
\hline & & & & & \\
Oryza coractata & lny=3.3089-0.01045X & 0.073 & 0.01045 & 66.32 & 9.475 \\
\hline
\end{tabular}




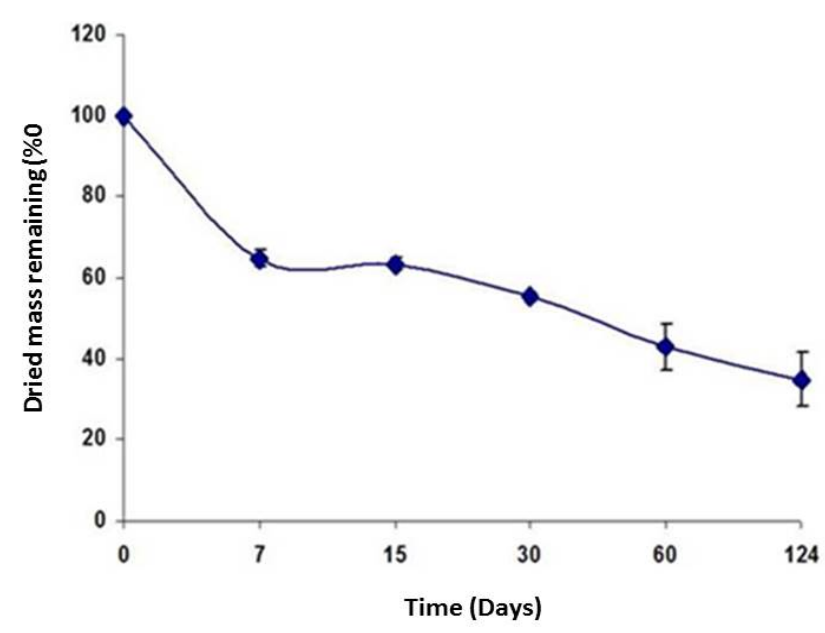

Figure 3 The percentage dried weight of decomposed Oryza coaractata. Remaining during the phase of decomposition.
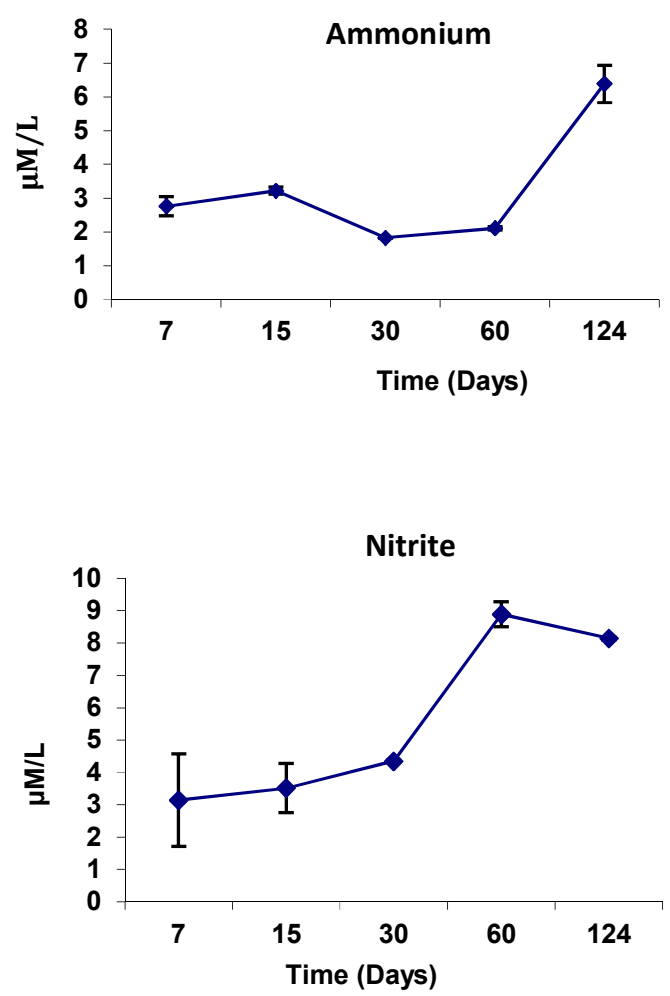

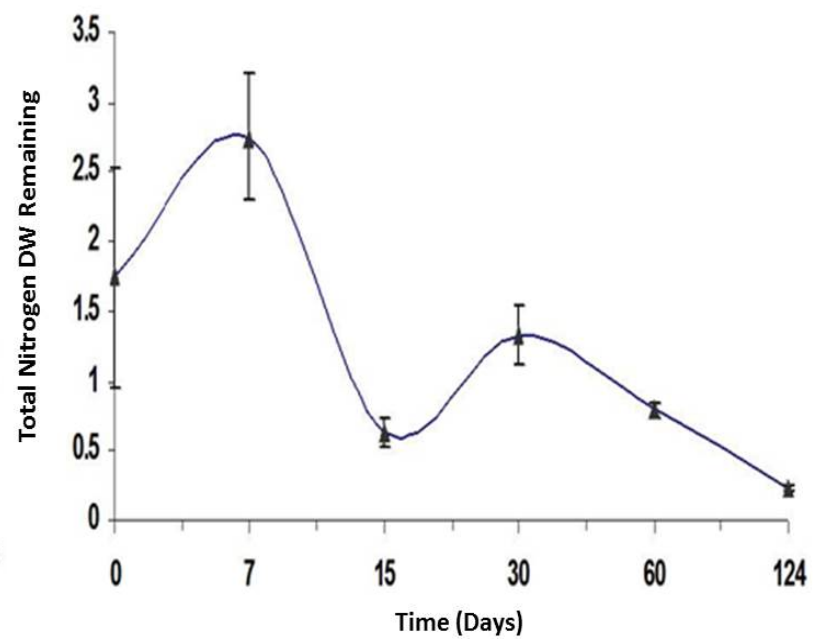

Figure 4 The total Nitrogen dry weight (DW) remaining in decomposed fragments of Oryza coaractata during the phase of decomposition in the Laboratory experiment.
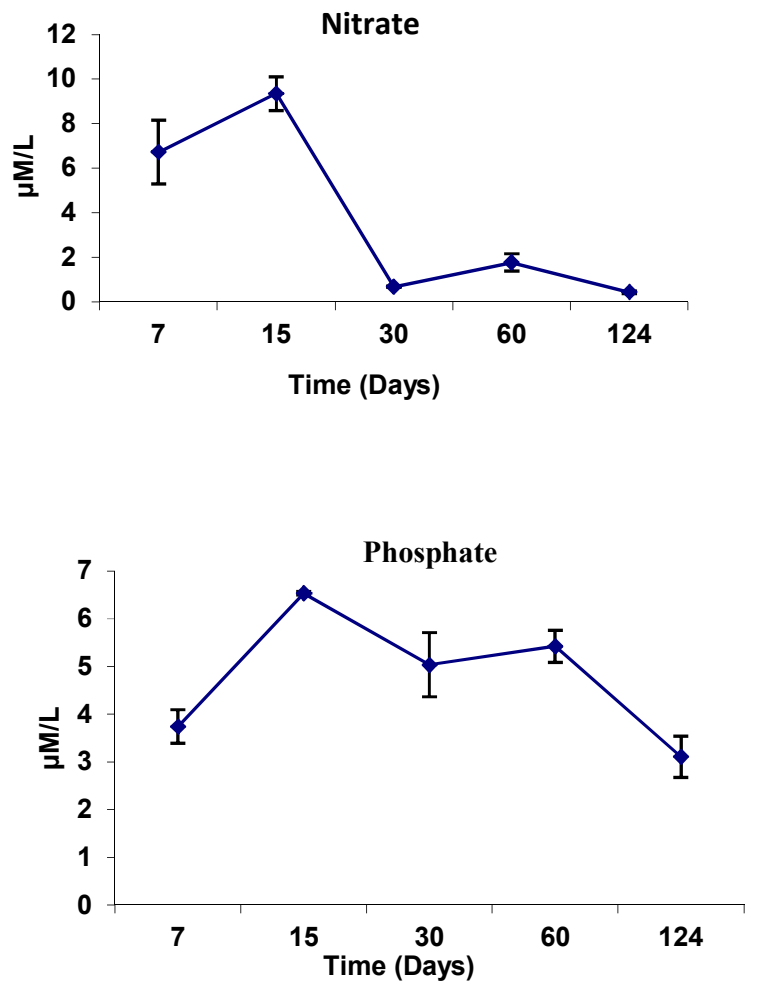

Figure 5 The concentration of various Nutrients ions (ammonoim, nitrate, nitrite, phosphate) remaining in the glass bottle during the phase of decomposition of Oryza coarctata. 


\section{Nitrates ions concentration}

The nitrate ion concentration was $1.95 \mu \mathrm{M} / \mathrm{L}$ at 7 th day and increased to $2.71 \mu \mathrm{M} / \mathrm{L}$ at 15 th day of decomposition, and afterwards the concentration of nitrate decreses gradually and lowest value $0.129 \mu \mathrm{M} / \mathrm{L}$ in the last day of the experiment was observed (Figure 5).

\section{Nitrite ions concentration}

The nitrite ions concentration was found 1.80 $\mu \mathrm{M} / \mathrm{L}$ and gradually increased to $3.33 \mu \mathrm{M} / \mathrm{L}$ at 60th day and the lowest value recorded was 3.05 $\mu \mathrm{M} / \mathrm{L}$ (Figure 5).

\section{Phosphate ions concentration}

The initial concentration of the phosphate ions was $0.84 \mu \mathrm{M} / \mathrm{L}$ and it decresed gradually during the phase of decomposition to its lowest value at $0.7 \mu \mathrm{M} / \mathrm{L}$ (Figure 5).

These results showed that that most of the organic material of the $O$. coarctata were leached out during the early phase of the decomposition, and thereby enhanced the nutrients quantities in the water. These results declared the fact that amount of the leached out material increased the nutrients availability in the form of the ammonium, nitrates, nitrites and phosphat ions to the surrounding/adjacent water.

\section{The corellation of Total Nitrogen and Nutrients ion values}

The results are also strongly correlated with the nutrients values. Figure 5 showed the nitrates and nitrites values were higher at the 15th day of the early phase of the decomposition. Therefore, it is evident from the results that most of the nitrogen material decomposed during the early phase of the decomposition was released in the form of nitrates and nitrites.

Our results strongly endorsed this contention, as early decomposition was highest during initial 7 days, when about $40 \%$ of the plant material was decomposed at this stage $2[9,16]$. The leaching of the moist plant or totally submerged defragmented material is faster than that of the dried material $[9,10]$. Valiela also suggest other $\mathrm{key} / \mathrm{major}$ factors, which result in the decay rates of plant materials. He emphasized on litter quality like chemistry of plant material and species to species variations [9].

The nitrogen content in leaves of Oryza coarctata, and other vegetation in the coastal region of the world, depend on several factors such as the nutrients conditions of Hajambro creek, from where the plants were collected, the age of leaves and the light availability [16, 17]. Different modes of decomposition of the sea grasses were found compared to other vascular plants such as marsh grasses and mangrove [10]. In contrast to other vascular plants, where net immobilization of $\mathrm{N}$ is evident [13], during the decay of the Oryza coaractata, the nitrogen and other elements are gradually released (Figure 4). This agrees with the observations of our study that leaves have undergone the early phase of decomposition with significant loss of Nitrogen $[16,17]$.

\section{CONCLUSIONS}

The importance of the vegetation, other than mangrove plants (Avicennia marina and Rhizophora mucronata) has been recognized, as these vegeta tion also has the role to supply nutrients after decomposition. Therefor, it is evident from the experiment that the Oryza coarctata leaves are the source of the nutrients to the adjacent coastal environement.

\section{ACKNOWLEDGMENT}

The Higher Education Commission of Pakistan is gratefully acknowledged for provi ding Indigenous Ph.D. Scholarship to the Mr. Zafar Frooqui for pursuing his $\mathrm{PhD}$ studies, 'Study on mangrove ecosystem with respect to Biodiversity, Productivity and Nutrient Dyna mics' in Keti Bunder, Hjambro creek, Indus delta. The study was conducted in a Laboratory of Center of Excellence in Marine Biology, University of Karachi. The Metrological depart ment, Karachi, provided the climate data.

\section{REFERENCES}

1. Siddiquie P.J.A, Sumera Farooq, Seema Shafique, Zaib-un-Nisa Burhan, Zafar Farooqui (2008) 
Conservation and management of Biodiversity in Pakistan through the establishment of marine protected areas, Ocean and Coastal Management. 51: 377-382.

2. Farooqui Z, Pirzada. Jamal, Siddiqui, Seema Shafique, Amjad Ali, Pervaiz Iqbal (2012) Assessment of litter production in semi arid mangroves forests near active Indus river mouth (Hajambro creek) and Karachi backwaters, Pakistan. Pak .J. Bot. 44(5): 1763-1768..

3. Blum LK, Mills AL (1991) Microbial growth and activity during the initial stages of seagrass decomposition. Marine Ecology Progress Series. 70: 73-82.

4. Buchsbaum R, Valiela I, Swain T, Dzierzeski M, Allen S (1991) Available and refractory nitrogen in detritus of coastal vascular plants and macroalgae. Marine Ecology Progress Series. 72: 131-143.

5. Mateo MA, Romero J (1997) Detritus dynamics in the seagrass Posidonia oceanica: elements for an ecosystem carbon and nutrient budget. Mar. Ecol. Prog. Ser. 151: 43-53.

6. Johnson P, Johnstone R (1995) Productivity and nutrient dynamics of tropical seagrass communities in Puttalam Lagoon, Sri Lanka. Ambio. 24: 411-417.

7. Hemminga MA, Slim FJ, Kazungu J, Ganssen GM, Nieuwenhuize J, Kruyt NM (1994) Carbon outwelling from a mangrove forest with adjacent seagrass beds and coral reefs (Gazi Bay, Kenya). Mar. Ecol. Prog. Ser. 106: 291-301.

8. Wafar S, Untawale AG, Wafar M (1997) Litter fall and energy flux in a mangrove ecosystem. Estuarine Coastal and Shelf Sci. 44: 111-124.

9. Valiela I, Rietsma CS (1995) Disturbance of salt marsh vegetation by wrack mats in Great Sippewissett Marsh. Oecologia. 102: 106-112.

10. Enriquez S, Duarte CM, Sand-Jensen K (1993) Patterns in decomposition rates among photosynthetic organisms: the importance of detritus C:N:P content. Oecologia. 94: 457-471.

11. Duarte CM (2000) Marine biodiversity and ecosystem services: an elusive link. J. Exp. Mar. Biol. Ecol. 250: 117-131.

12. Duarte CM (1989) Temporal biomass variability and production/biomass relationships of seagrass communities. Mar. Ecol. Prog. Ser. 51: 269-276.

13. Seema shafique,Pirzada J.A.Siddiqui,Rahila Abdul Aziz and Nafisa Shoaib.(2013)Variation in carbon and nitrogen contents during decomposition of three macroalgae inhabiting sandspit backwater, Karachi.Pak.J. Bot. 45(3:1115-1118.

14. Wells and Coleman, 1984. Deltaic morphology and sedimetology, with especial reference to Indus river delta. In: B.U. Haq and J.D. Milliman, (eds.). Marine Geology and Oceanography of
Arabian Sea and Coastal Pakistan. Van Nostrand Reinhold Co., N.Y. pp. 85 - 100.

15. Roberts TJ (1995) A pictorial view of the Indus River and mans impact on its role and resources. In The Indus River, Biodiversity, Resources and Humankind, Eds. Meadows A and Madows P. Oxford University Press. Pakistan. 91-99.

16. Duarte CM, Cebrian J (1997) The fate of marine autotrophic production. Limnol Oceanogr. 41: 1758-1766.

17. Duarte CM, Middelburg J, Caraco N (2005) Major role of marine vegetation on the oceanic carbon cycle. Biogeosciences. 2: 1-18. 
